\title{
Evaluation of Antibacterial Property of Cell-free Hemolymph and Hemocytes of Marine Gastropod, Rapana Rapiformis from Inshore Waters of Pondicherry, Southeast Coast of India
}

\section{S. Amruthalakshmi ${ }^{1}$, A. Yogamoorthi ${ }^{2 *}$}

${ }^{1}$ PG Student, Department of Ecology \& Environmental Sciences, Pondicherry University, Pondicherry-605014, INDIA

${ }^{2}$ Associate Professor, Department of Ecology \& Environmental Sciences, Pondicherry University, Pondicherry-605 014, INDIA

Email: ultrayoga1@gmail.com

\begin{abstract}
The cell -free hemolymph and hemocytes isolated from body-fluid of marine gastropod Rapana rapiformis distributed in the shallow waters of Pondichery coast, were tested for their antibiotic potential against five common human bacterial pathogens viz. Klebsiella pneumonia, Staphylococcus aureus, Pseudomonas aeruginosa, Vibrio cholera and E.Coli. The sensitivity test thro Disc diffusion assay revealed that cell-free hemolymph of Rapana rapiformis exhibited higher level of inhibition even at MIC of 2.5ul against Vibrio cholera when compared to reference drug. A peptide molecule in haemolymph that showed higher inhibitory activity with the molecular mass of $35 \mathrm{kDa}$, has been found by Sodium Dodecyl Sulphate Polyacrylamide gel electrophoresis. It could be of greater interest to isolate and characterize this protein which might be used commercially against existing antibiotic resistant strains such as MRSA in future.
\end{abstract}

Keywords: Marine gastropod-Rapana rapiformis-antibacterial-vibrio cholera-low molecular peptide

This article is is licensed under a Creative Commons Attribution-NonCommercial 4.0 International License.

Attribution-NonCommercial (CC BY-NC) license lets others remix, tweak, and build upon work non-commercially, and although the new works must also

acknowledge \& be non-commercial.

\section{INTRODUCTION}

Molluscs are widely distributed throughout the world and have many representatives such as slugs, whelks, clams, mussels, gastropods, oysters, scallops, squids and octopods in the marine and estuarine ecosystem (Sharmin Vini et al 2013). Many classes of bioactive compounds exhibiting anti-tumor, anti-leukemic, antibacterial and antiviral activities have been reported worldwide in these group of animals (Rajaganapathy et al., 2000). Among mollusks, some have pronounced pharmacological activities or other properties which are useful in the biomedical area. In addition to the tissue borne secondary metabolites, other components viz. hemolymph and hemocytes are also reported to possess potential bioactive principle across the invertebrates including insects. Molluscan haemocytes stering in the hemolymph are involved with variety of important physiological processes including recognition and elimination of foreign materials, shell repair, wound repair, nutrient distribution and excretion (Armstrong et al 1971: Cheng 1984, Pollero, Huca and Brenuer 1985; Chen and Bayne 1995; Mount et al 2004). Haemocytes which behave like phagocytes are also serve a role in the molluscan stress response involving endocrine molecules (Ottavini, Franchini and Fontalli 1992; Ottavini and Franceshi 1996). Screening studies on antibiotic property and active peptide present in hemolymph and such potential in hemocytes of gastropod body fluid is very meager when compared to studies in insects' hemolymph. Important reports relating to hemolymph bioactive potential in insects viz. Diplopods and Chilopods (Xylander \& Neverman,1990,Nevermann et al 1996); crabs viz. Scylla serrata (Anitha, 
et al 2011); horse shoe crab(Saito et al 1995), Carcinus menas (Julit et al 1999;),Ocypoda macrocera (Pitchaia Sivaperumal et al 2013) and gastropods viz. Nerita albicilla, (Sharmin Vini et al 2013); Dromia abrolhensi (Rameshkumar et al 2009) attracted pharmacologist to focus their search for potential secondary metabolites /property in the hemolymph of marine gastropods.

In the present study, an attempt has been made to evaluate the antibacterial property of cell-free haemolymph and hemocytes of the marine gastropod Rapana rapiformis against different human pathogens and to ascertain the molecular weight of the protein peptide using SDS-PAGE present in haemolymph responsible for antibacterial property.

\section{Materials AND Methods}

Gastropod, Rapana rapiformis is a species of sea snail or marine gastropod mollusk. It is also known as rock snail or murex snail. The colour of the shell is uniform orange-brown; light brown with 3-4 chocolate brown bands on body, the aperture is white with operculum oval in shape. The length of the animal varies from 22.90 to102.60 mm, diameter from 17.90 to $84.76 \mathrm{~mm}$. The max height of the aperture is 9.60 to $83.75 \mathrm{~mm}$ and height of spire is 8.49 to $33.68 \mathrm{~mm}$. Live animals are collected alive from fishing launches operating in the inshore waters of Pondicherry, southeast coast of south India.

\section{Collection of haemolymph \& isolation of hemocytes}

The haemolymph was obtained from the opercular region between the shell and mantle tissue using sterile $5 \mathrm{ml}$ syringe and needle. Totally $12 \mathrm{ml}$ of haemolymph was collected from 6 animals. The haemolymph was centrifuged at $10000 \mathrm{rpm}$ for 30 minutes to separate hemocytr5es. The supernatant was collected and stored at $-4^{\circ} \mathrm{C}$. The haemocytes were also separated and stored in the same way for further use (Fig.1a \&1b).

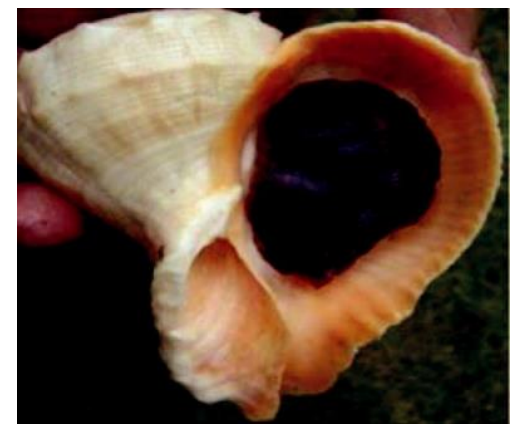

Figure 1a: Rapana rapiformis

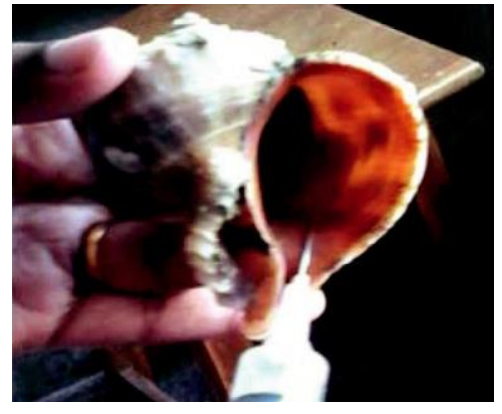

Figure 1b: Collection of Haemolymph

\section{Antibacterial assay}

The bacterial strains used for sensitivity test were Klebsiella pneumonia, Staphylococcus aureus, Pseudomonas aeruginosa, Vibrio cholera and E.Coli obtained from the stock available in the department.

\section{Disc Diffusion Method}

The antibacterial activity of cell-free haemolymph and hemocytes collected marine gastropod Rapana rapiformis was against five strains viz, Klebsiella pneumonia, Staphylococcus aureus, Pseudomonas aeruginosa, Vibrio cholera and E.Coli. Nutrient broth medium (MullerHinton agar) was prepared and sterilized at 121lbs for 15minutes. Invitro antibacterial assay were conducted using the standard disk-diffusion method (McCaffrey and Endean., 1985). 20uL of the sample was impregnated to what man No.1 filter paper. Disks with standard antibiotics (Erythromycin and Ampicillin) were also prepared and allowed to dry at room temperature. Further they were aseptically placed on the agar plates swabbed with the test microorganisms. The plates were incubated at $37^{\circ} \mathrm{C}$ for 24 hours. The antibacterial activity was measured accordingly based on the zone of inhibition around the disk impregnated with haemolymph. (Sharmin Vini et al 2013) using standard scale obtained from Hi-media.

\section{Sodium Dodecyl Susfate-Poly Acrylamide Gel Electrophoresis}

One-dimensional SDS-PAGE was performed using standard methods on the Bio-Rad Mini-Protean II system. It is discontinuous system with $12 \%$ separating gel $(\mathrm{pH}$ 6.8) of size $7 \mathrm{~cm} \times 10 \mathrm{~cm} \times 1 \mathrm{~cm}$. Prior to electrophoresis, protein samples were redissolved in Laemmli buffer (Laemmli, 1970) and boiled in the presence of dithiotheriotol (DDT) for $5 \mathrm{~min}$ at $100^{\circ} \mathrm{C}$. For the molecular weight markers, Sigma marker wide molecular weight range (sigma) was used. The electrophoresis was performed at 10Ma per gel. The gels were stained with Brilliant Blue R concentrate (Sigma- 
Aldrich) for 30mins and were destained in $50 \%(\mathrm{v} / \mathrm{v})$ methanol, $5 \%(\mathrm{v} / \mathrm{v})$ acetic acid for 30mins or until band appeared.

\section{REsUlts}

\section{Antibacterial activity study}

The antibacterial activity of haemolymph and haemocytes of Rapana rapiformis was measured as radius of zone of inhibition (diameter in $\mathrm{mm}$ ) around the disc in comparison with the standard drugs Ampicilin and Erythromycin. The haemolymph of Rapana rapiformis showed significant inhibitory effect against human pathogenic bacteria Vibrio cholerae, whereas haemocytes showed higher activity against Vibrio cholerae, Psuedomonas aeruginosa and Escherichia coli (Fig.2). The haemolymph was ineffective against the other four human bacterial pathogens such as Psuedomonas aeruginosa, Klebsiella pneumonia, Escherichia coli, and Staphylococcus aureus and haemocytes were ineffective against Staphylococcus aureus and Klebsiella pneumonia as shown in Tables $1 \& 2$ and Figs. $2 \& 3$ respectively. The minimum inhibition concentration (MIC) for haemolymph against the pathogen Vibrio cholerae was obtained as 2.5ul whereas concentration of haemocytes against Vibrio cholerae is 5.0 $\mathrm{ul}$. Escherichia coli and their MIC values for both was 5.0ul.

Table: 1 Antibacterial activity of Haemolymph of Rapana rapiformis against different human pathogen

\begin{tabular}{|l|c|c|c|}
\hline \multirow{2}{*}{ Tested pathogens } & \multicolumn{3}{|c|}{ Zone of inhibition(mm) } \\
\cline { 2 - 4 } & Haemolymph $\mathbf{( m m})$ & \multicolumn{2}{|c|}{ Reference Drugs (mm) } \\
\cline { 2 - 4 } & $\mathbf{2 0} \mathbf{l}$ /disc & Erythromycin (10ug/ml) & Ampicilin (10ug/ml) \\
\hline Vibrio cholera & 26 & 27 & 25 \\
\hline Klebsiella pneumonia & Nil & 26 & 22 \\
\hline Staphylococcus aureus & Nil & 27 & 25 \\
\hline Psuedomonas aeruginosa & Nil & 26 & 24 \\
\hline E. coli & Nil & 24 & 26 \\
\hline
\end{tabular}
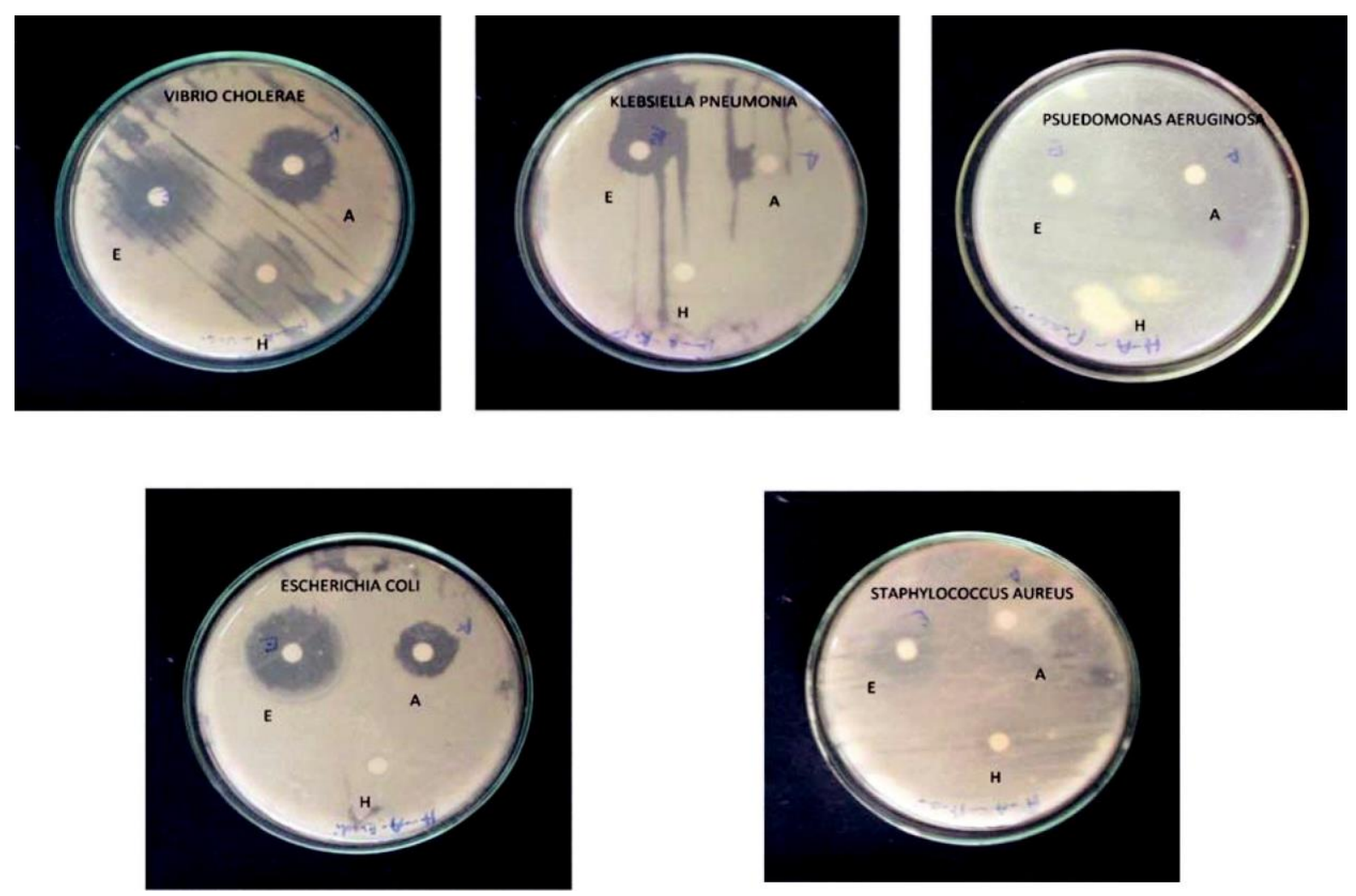

Figure 2: Antibacterial activity of Haemolymph of Rapana rapiformis against different Human pathogens E Erythromycin A- Ampicilin H- Haemolymph 
Table 2: Antibacterial activities of Haemocytes of Rapana rapiformis against different human pathogens

\begin{tabular}{|l|c|c|c|}
\hline \multirow{2}{*}{ Tested pathogens } & \multicolumn{3}{|c|}{ Zone of inhibition(mm) } \\
\cline { 2 - 4 } & Haemoytes $(\mathbf{m m})$ & \multicolumn{2}{|c|}{ Reference Drugs(mm) } \\
\cline { 2 - 4 } & $\mathbf{2 0} \mathbf{l}$ /disc & 28 & Ampicilin (10ug/ml) \\
\hline Vibrio cholera & 20 & 14 & 18 \\
\hline Klebsiella pneumonia & Nil & 15 & 21 \\
\hline Staphylococcus aureus & Nil & 32 & 25 \\
\hline Psuedomonas aeruginosa & 25 & 31 & 21 \\
\hline E. coli & 19 & & 18 \\
\hline
\end{tabular}
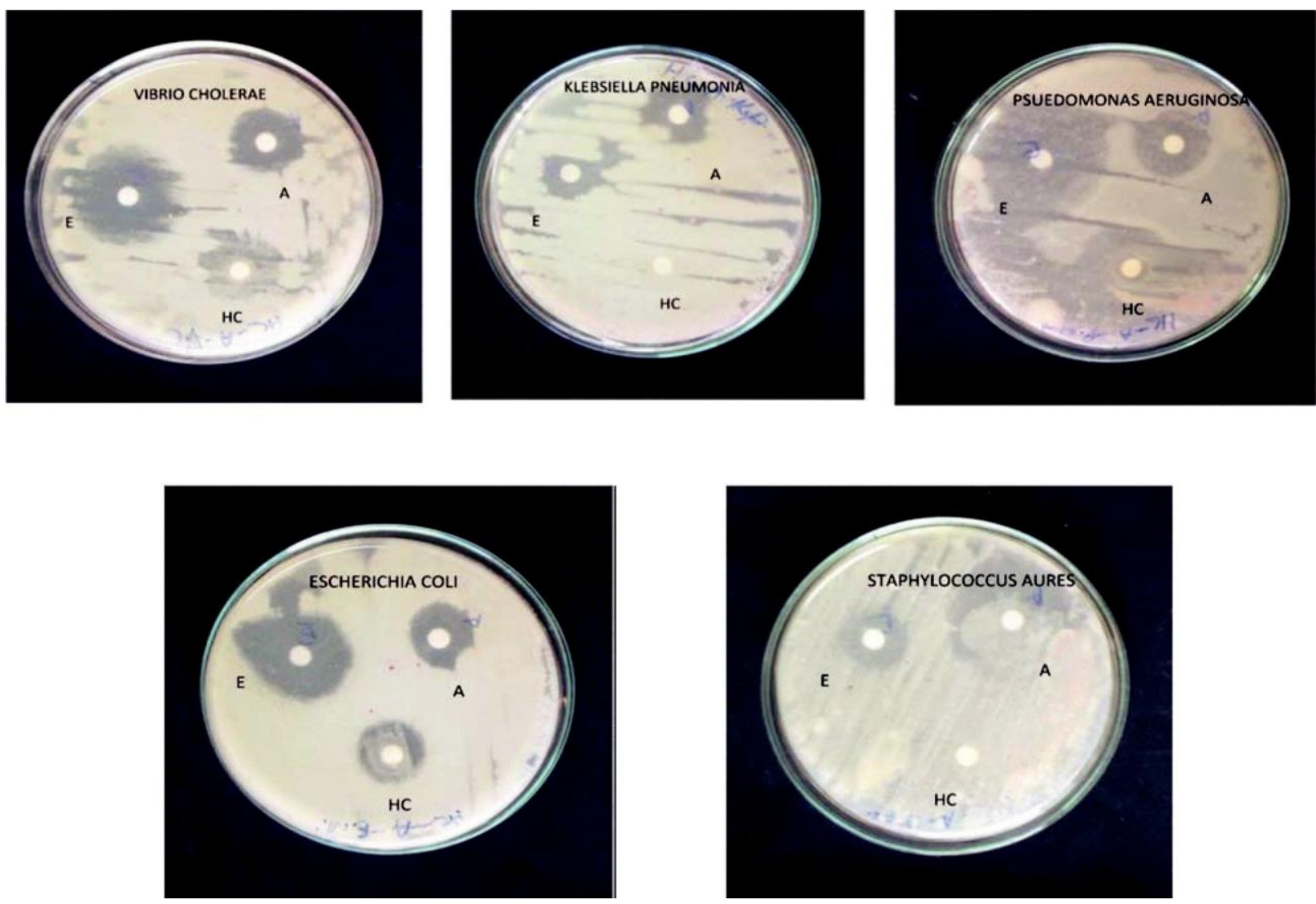

Figure 3: Antibacterial activity of Haemocytes of Rapana rapiformis against different human pathogens EErythromycin A- Ampicilin H- Haemocytes.

Table 3: Minimum Inhibition Concentrations (MIC)

\begin{tabular}{|l|c|c|}
\hline Name of the pathogen & Concentration of Haemolymph (ul) & Concentration of Haemocytes (ul) \\
\hline Vibrio cholera & 2.5 & 5.0 \\
\hline Klebsiella pneumonia & No activity & No activity \\
\hline Psuedomonas aeruginosa & No activity & 5.0 \\
\hline Staphylococcus aureus & No activity & No activity \\
\hline Escherichia coli & No activity & 5.0 \\
\hline
\end{tabular}

\section{SDS GEL Electrophoresis}

A peptide molecule in haemolymph with the molecular mass of $35 \mathrm{kDa}$ has been found by Sodium Dodecyl Sulphate Polyacrylamide gel electrophoresis 


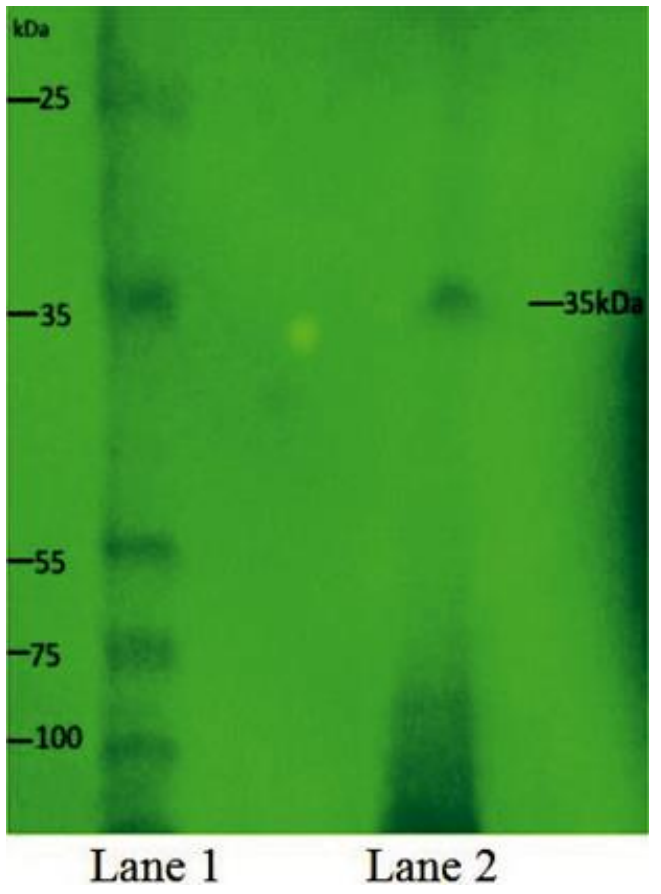

Figure 4: SDS PAGE for hemolymph

Lane 1-Standard protein marker Lane 2-Sample (Haemolymph)

\section{Discussion}

The emergence of new infectious diseases and development of resistance to the antibiotics by the existing ones led to search for new but better potent source of antibiotic. This field of research receives the attention of investigators from various fields such as marine biology, marine microbial ecology, biochemistry, chemistry, pharmacology and biotechnology. In the industrialized countries, about $25 \%$ of all prescribed drugs contain active principles that are still extracted from higher plants. Consequently there is growing interest in marine natural products or marineborne secondary metabolites (Sharmin Vini et al. 2013). Human studies on antibacterial property of haemolymph of gastropods are very meager. In the present study hemolymph and haemocytes isolated from marine gastropod Rapana rapiformis, have been evaluated for its antibacterial property. Vibrio cholerae have shown higher sensitivity among the tested pathogens with a zone of inhibition of $26 \mathrm{~mm}$. And the test of hemocytes revealed that hemocytes have shown activity against three human pathogens such as Vibrio cholerae, Psuedomonas aeruginosa and Esherichia coli with a zone of inhibition of $20 \mathrm{~mm}, 25 \mathrm{~mm}$, and $21 \mathrm{~mm}$ respectively. Similar observation was made by Sharmin Vini et al.( 2013) where the antimicrobial activity the zone of inhibition $8 \mathrm{~mm}$ was recorded against B.subtilis, K.pneumonia and S.typhi, by the hemolymph of gastropod Nerita albicilla and the similar trend was also recorded against E.coli, K.pneumonia and S.aureus, by the hemolymph of Purpura bufo, another marine gastropod(Sharmin Vini et al.( 2013). Further an attempt was made to assertain the active peptide present in the haemolymph of Rapana rapiformis through the SDS-PAGE revealed that the hemolymph Rapana rapiformis possess a protein with molecular mass of $35 \mathrm{kDa}$. Similarl protein was also found in hemolymph of shore crab Ocypoda macrocera MW ranging between 15.43 to 60.34kDa. (Pitchiah 28 Sivaperumal et al., 2013). A 27kDa protein was purified from horse-shoe crab hemocyte (Saito et al., 1995.). Another antibacterial protein of 11.5kDa was purified and characterised from Carcinus maenas which is cationic and hydrophobic in nature and showed inhibition only against marine gram-positive bacteria (Juliet et al., 1999). Protein estimation in cell free and precipitated haemolymph of crab species Scylla serrata and Metagrapsus messor showed remarkable variations. SDS-PAGE showed many protein bands with molecular size ranging from 22 to 60KDa. Similarly SDS-PAGE of haemocyte contents showed protein bands with molecular size ranging from 22 to 91KDa was reported.(Samuthirapandian et al., (2010). Likewise Pan et al., (2008) reported two bands at molecular weight around 73 and $75 \mathrm{KDa}$ from haemocyte Bombyx mori. Low molecular peptides were also isolated from the haemolymph of various insects. The haemolymph of diplopod as a reference showed that its lysozyme had a molecular weight of 14.5kDa (Xylander et al 1997). From chilopod haemolymph low molecular peptides ranging from 15.5 to $16.5 \mathrm{kDa}$ was isolated by Xylander (2009). Reports on haemolymph antibiotic peptides also emphasis that in insects which lack an adaptive immune system, antimicrobial peptides play a crucial role in fighting invading pathogens. They are synthesized in response to microbial infection or septic body injury mainly in insect 
fat body (functional equivalent of mammalian liver) and in certain blood cells, and then rapidly released into hemolymph where they act synergistically against microorganisms. (Tzou et al., 2002; Dunphy et al., 2003 and Irving et al., 2004). Similarly, it is presumed that circulating haemolymph with hemocytes in marine invertebrates contains biologically active substances such as complement, lectins, clotting factors, antimicrobial peptides and lipids such as fatty alcohols, free fatty acids and monoglycerides (Miyata et al,1989;Thomar et al.,2007). Therefore, it could be of greater interest to isolate and characterize this protein which might be used commercially against those resistant strains because it has become a normal feature that bacteria are developing resistance to antibiotic after several uses. Concludingly, based on present findings on the antibiotic peptides present in the hemolymph and reports on various invertebrates particularly in gastropods, it could be stated that body fluid of invertebrates i.e. hemolymph and streaming hemocytes are found to be potential source of antibiotic and further confirmation, isolation purification and characterization of those active peptides would help to combat antibacterial resistant microbial pathogenicity like Methicillin resistant Staphylococcus aureus ( MRSA).

\section{REFERENCES}

Anitha and K. Sharath, Antimicrobial peptides from the haemolymph of crabs Scylla serrata and Metapograpsus messor. Asiatic Journal of Biotechnology Resources; 2011, 2 (5) 568-576.

Armstrong A D, Armstrong J L, Krassner S M and Pauley G B.,. Experimental wound repair in the black abalone, Holiotis cracherodii. Journal of Invertebrate Pathology, 1971, 17: 216-227

Chen J H and Bayne C J., Bivalve mollusk haemocyte behaviors: Charecterisation of hemocytes aggregation and adhesion and their inhibition in the california mussel (mytilus californianus).Biological bulletin, 1995, 188:255-266.

Cheng, T. C., A classification of molluscan hemocytes based on functional evidences. In Invertebrate Blood, 1984, 111-146.

Dunphy, G.B., U. Oberholzer, M. Whiteway, R.J. Zakarian and I. Boomer. Virulence of Candida albicans mutants toward larvae of Galleria mellonella (Insecta, Lepidoptera, Galleridae). Can J Microbiol, 2003, 49:514-524.

Irving, P., L. Troxler and C. Hetru, Is innate enough? The innate immune response in Drosophila. CR Biol.2004, 327: 557-570.

Jarosz, J., G. Kania \& M. Balcerzak,Cell-free immune entities of four diplopod myriapods. - In: Program and abstracts, XXIVAnnual Meeting, Society for Invertebrate Pathology, Flagstaff, Arizona, 4.-9.8.1991: 100.

Juliet, M.Relf, June R.S.Chisholm, Graham D.Kemp and Valerie J.Smith, Purififaction and characterization of a cysteine-rich $11.5 \mathrm{kDa}$ antibacterial protein from granula hemocytes of the shore crab, Crcinus maenas. Eur.J.Biochem.1999, 267:677-683.

Laemmli, U. K. Cleavage of structural proteins during the assembly of the head of bacteriophage T4. Nature, 1970, 227(5259), 680685. McCaffrey, E. J., \& Endean, R.Antimicrobial activity of tropical and subtropical sponges. Marine Biology, 1985, 89(1), 1-8.

Miyata, T., Tokunaga, F., Yoneya, T., Yoshikawa, K., Iwanaga, S., Niwa, M., \& Shimonishi, Y.Antimicrobial peptides, isolated from horseshoe crab hemocytes, tachyplesin II, and polyphemusins I and II: chemical structures and biological activity. Journal of biochemistry, 1989, 106(4), 663-668.

Mount A S, Wheeler A P, Paradkar R P and Snider D. Hemocytes-mediated shell mineralisation in the eastern oyster. Science, 2004,304, 297-300.

Nevermann, L. \& W. E. R. Xylander,In vitro cellular immune reactions of hemocytes against bacteria and their differential degradation in myriapods. - In: Geoffroy, J.-J., Mauries \& M. Nguyen Duy-Jacquemin (eds): Acta Myriapodologica Mémoires du Muséum national d'Histoire naturelle, 199, 169, 421- 430.

Nevermann, L., H. E. Kaiser \& W. E. R Xylander,Microbial induced haemocytic immune reactions in chilopods. - In Vivo, 1996,10, 161-168.

Ottavini E, Caselgrandi, Petraglia F and Francheschi C, Stress responses in the freshwater snail plauorbarius corneus (1.) (gastropoda, plumonata):interaction between CRF, ACTH and biogenic amines. General and comparitive endocrinology 1996, 87(3), 354-360.

Ottavini E, Franchini A, Fontanili P,The presence of immunoreactive vertebrate bioactive peptide substances in hemocytes of the freshwater snail viviparus ater (gastropoda, prosobranchia). Cellular and molecular neurobiology, 1992. 12,455-462.

Pan, J. Y., Zhang, Y. L., Wang, S. Y., \& Peng, X. X. Dodecamer is required for agglutination of Litopenaeus vannamei hemocyanin with bacterial cells and red blood cells. Marine Biotechnology, 2008, 10(6), 645-652.

Pitchiah Sivaperumal, Kannan Kamala, Elayaperumal Natarajan, Elangovan Dilipan., Antimicrobial peptide from crab haemolymph of Ocypoda macrocera (Milne Edwards 1852) with reference to antioxidant: a case study. Int J Pharm Pharm Sci, 2013, 5, 719-727.

Pollero R J, Huca G and Brenuer, Role of hemocytes and plasma on lipid transport in fresh water mollusc Diplodon delodontus. Comparitive biochemistry and physiology, 1985, 82,339-343.

Rajaganapathy, J., Kathiresan, K and Sing, T.P, Purification Anti-HIV protein from purple fluid of the seahare Bursatella leachii de Blainville. J. Mar. Biotechnol, 2000, 4,447-453.

Rameshkumar, G., Ravichandran, S., Kaliyavarathan, G., \& Ajithkumar, T. T. Antimicrobial peptide from the crab, Thalamita 
crenata (Latreille, 1829). World J Fish Mar Sci, 2009, 1(2), 74-79.

Rameshkumar, G., S. Ravichandran and T. Aravindhan, Antimicrobial Proteins from the Crab Charybdis lucifera (Fabricius, 1798). Middle East J. Sci. Res, 2009, 4, 40-43.

Rinehart, K.L., P.D. Shaw, L.S. Shield, J.B. Gloer, G.C. Harbour and M.E.S. Koker, Marine naturaL products as sources of antiviral, antimicrobial and antineoplastic agents. Pure and Applied Chemistry, 1981, 53, 795-817.

Saito, T.S. Kawabata, M.Hirata and S.Iwanaga, A novel type of Limulus Lectin-6: purification, primary structure and antibacterial activity. The American Society for Biochemistry and Molecular Biology, 1995, 270, 14493-14499.

Samuthirapandian Ravichandran, Singaram Jeyalakshmi, Sathasivam Sudha and Ramasamy Anbuchezhian, Antimicrobial peptides from the haemolymph of the prawn Macrobrachium rosenbergii. Bangladesh J. Pharmacol.2010, 5, 62-67.

Seraj, U. M., Hoq, M. I., Anwar, M. N., \& Chowdhury, A 61kDa Antibacterial Protein Isolated and Purified from the Hemolymph of the American Cockroach Periplaneta amreicana. Pakistan Journal of Biological Sciences, 2003, 6(7), 715-720.

Sharmin Vini, S., Asha, A., Viju N., Sunjaiy Shankar, C. V. and Mary Josephine Punitha.S, Antibacterial activity of hemolymph of selected gastropods sps collected from kanyakumari coast against human pathogens. International Journal of Current Research, 2013, 5(12), 4066-4069.

Thormar, H., \& Hilmarsson, H. The role of microbicidal lipids in host defense against pathogens and their potential as therapeutic agents. Chemistry and physics of lipids, 2007, 150(1), 1-11.

Tzou, P., E. De Gregorio and B. Lemaitre, (2002). How Drosophila combats microbial infections: a model to study innate immunity and host -pathogen interactions. Curr Opin Microbiol.2002, 5, 102-110.

Van der Walt, E., L. McClain, A. Puren \& N. Savage,Phylogeny of arthropod immunity. An inducible humoral response in the Kalahari millipede, Triaenostreptus triodus (Attems). - Naturwissenschaften, 1990, 77, 89-90.

Xylander, W. E. Epidermis and sensory receptors of Temnocephala minor (Plathelminthes, Rhabdocoela, Temnocephalida): an electron microscopic study. Zoomorphology, 1997, 117(3), 147-154.

Xylander, W. E. Physico-chemical properties of haemolymph of Chilopoda and Diplopoda (Myriapoda, Arthropoda): protein content, pH, osmolarity. Soil Org, 2009, 81, 431-439.

Xylander, W. E. R. \& L. Nevermann, Antibacterial activity in the hemolymph of Myriapoda (Arthropoda). - Journal of Invertebrate Pathology, 1990, 56(2), 206-214

Xylander, W. E. R. Antibacterial substances from the hemolymph of various myriapods. -Symposium on Invertebrate Immunology, Lecce/Italy, 1989, 25. Abstracts: 33.

Xylander, W. E. R. Immune defense reactions of Myriapoda - A brief presentation of recent results. In: Thaler, K., E. Meyer \& W. Schedl (eds): Advances in Myriapodology (Proceedings of the 8th International Congress of Myriapodology). - Berichte des naturwissenschaftlich-medizinischen Vereines Innsbruck, Suppl.1992, 10, 101-110.

$$
\text { -- } 0 \text {-- }
$$


